\title{
Should Beijing Worry about Warming Relations between Burma and the United States?
}

\section{David Péneau}

Translator. Kate Waller

\section{OpenEdition \\ Journals}

\section{Electronic version}

URL: http://journals.openedition.org/chinaperspectives/6192

DOI: 10.4000/chinaperspectives.6192

ISSN: 1996-4617

\section{Publisher}

Centre d'étude français sur la Chine contemporaine

\section{Printed version}

Date of publication: 1 June 2013

Number of pages: $76-78$

ISSN: 2070-3449

Electronic reference

David Péneau, «Should Beijing Worry about Warming Relations between Burma and the United States? », China Perspectives [Online], 2013/2 | 2013, Online since 01 June 2013, connection on 15 September 2020. URL : http://journals.openedition.org/chinaperspectives/6192 


\section{Should Beijing Worry about Warming Relations between Burma and the United States?}

\section{Analysis by David Péneau based on:}

- Li Yibo, “缅甸: 美军在亚太的下一朵 '睡莲”' (Is Burma the American Army's Next Water Lily in Asia?), Huanqiu wang, 7 December 2012.

- Shi Qingren, (1) "美国意图制衡中国在缅甸的影响力" (The United States' Objective is to Counterbalance Chinese Influence in Burma), Zhongguo qingnian bao, 4 January 2013.

- Wang Dong, (2) “中国该如何应对缅甸之 '变' " (How Should China React to the Current 'Changes' in Burma?), Huanqiu wang, 5 December 2012.

- Xiao Ke, (3) “缅甸改革及其前景刍议” (Reflections on the Burmese Revolution and its Perspectives), Xiandai guoji guanxi, No. 10, 2012.

- Zhou Xinyu, (4) “美国对缅政策调整述评” (Comments on the Shift of the United States' Policy in Burma), Xiandai guoji guanxi, No. 2, 2012.

D uring the span of two years, ${ }^{(6)}$ in the eyes of the United States (US) Burma has gone from a pariah state - once referred to as "a rogue state" - to a country that has initiated democratic reforms and which should be encouraged. The thawing of the relationship between the two countries was made tangible by Hillary Clinton and Barack Obama's historic visits (in November 2011 and December 2012, respectively). However, the Sino-Burmese relationship is still marred by the economic and commercial sanctions ${ }^{(7)}$ put in place by the United States in the aftermath of General Saw Maung's bloody coup d'État in 1988. This economic and diplomatic isolation of Burma has encouraged the development of a special relationship with China. China has constructed roads and pipelines in this neighbouring country and continues to exploit Burma's natural resources.

The sudden thaw in diplomatic relations with the US and Europe has completely transformed Burma's perspective within a two-year period. How do the Chinese media perceive US interest in a country that Beijing considers strategic for its security?

All of the five selected articles comment on the reforms currently taking place in Burma. All of them question the Burmese and American motivations that direct this tighter relationship, and what it means for China.

Indeed, the authors describe at length the strategic importance that Burma holds for China. It is first and foremost a "bridge," explains Li Yibo, between China and the Indian Ocean, a geographical link that would allow Beijing to resolve the "Malacca dilemma" (8) (maliujia kunju 马六甲困局), of which the authors are well aware. Beijing is building a pipeline between Yunnan and the port city of Kyaukpyu in hopes of one day carrying fuel imported from Africa and the Middle East. With no expense spared, China is also renovating the mythical "Burmese route" (Mandalay-Kunming), which following its use in the transport of American weapons for the Kuomintang during World War II could become the most prominent canal of SinoBurmese trade. Burma's natural resources (oil, copper, hydraulic energy) are coveted by the Chinese authorities.

Beyond the strategic interest that Burma represents for China, the five articles recount the historic relations between the two countries, which are founded in part, according to Xiao Ke, on a shared history of Japanese colonialism, common economic interests, and China's support for Burma when it was ostracised. For all these reasons, the Sino-Burmese relationship is, for the authors, special and inevitably close. It is worth noting that the authors do not fail to remark that in both Chinese and Burmese, this relationship is known by an evocative term: paukphaw (baobo 胞波 in Chinese). ${ }^{(9)}$

\section{The Burmese agenda: To break free from economic and commercial sanctions or to move away from China's sphere of influence?}

Each of the authors offers an explanation for the reasons that led Burmese president Thein Sein to turn towards the United States. Behind

1. Shi Qingren is a researcher at the Centre of Research for National Defence Policy of the Academy of Military Sciences of the People's Liberation Army (the PLA's most influential think-tank).

2. China Youth Daily is the official journal of the Communist Youth League of China.

3. Wang Dong has a degree in foreign policy from China East Normal University.

4. Xiao Ke is an associate professor at China North-East Normal University (School of Politics and Law). His research is in fundamental theory of political science.

5. Zhou Xinyu is a professor at the School of Foreign Languages in Beijing (School of International Relations and Diplomacy). His research areas notably include American foreign policy, China's rising power, and Chinese public diplomacy.

6. We may symbolically date the beginning of Burma's political transition with the liberation of Aung San Suu Kyi on 13 November 2010. The dissolution of the State Peace and Development Council and the resignation of General Than Shwe on 30 March 2011 signalled the end of the junta, which has given way to the elected civil government of President Thein Sein. The latter launched several reforms towards a democratisation of the country (easing of censorship, freeing of political prisoners, etc.).

7. The United States, the European Union, Australia, and Canada put in place widespread sanctions against Burma after 1988: forbidding imports, embargo on weapons, freezing trade relations and investments, forbidding visas for certain leaders, and freezing their assets abroad. These sanctions are gradually being removed following the progress of democratic reforms. Secretary of State Hillary Clinton notably announced the partial lifting of commercial sanctions against Burma in September 2012.

8. $80 \%$ of Chinese oil imports ship through the Strait of Malacca.

9. Baobo (胞波) in Chinese comes directly from the Burmese word paukphaw, which refers to a very close relationship. In Burmese as in Chinese, this term is exclusively used to describe Burma-China relations. 
this flip-flop, there would be purely pragmatic reasons resulting from Burma's eagerness to break the economic sanctions that have been weighing on it since 1988. With the Americans playing a game of carrot and stick, Zhou Xinyu explains that the Burmese authorities had no choice but to reform the regime in the hopes of ending the sanctions. John Blaxland, an Australian expert on Burma cited by Li Yibo, also explains that Burma does not wish to develop particularly close ties with the US but that it only seeks "some breathing room" (huxi kongijan 呼吸 空间). According to Li, China should not worry much about this closer relationship.

Surprisingly, Li Qingren is the only one to mention the fact that the better disposition of the Burmese government towards the US could also be the consequence of China's "rise" (jueqi 崛起), which has created a certain anxiety among its neighbours. According to Li, Burma's closer relationship with the US is not explained by economic reasons alone but also by its desire to acquire some "strategic room to manoeuvre" (zhanlüe huixuanyudi 战略回 旋余地) by multiplying its partners.

\section{Criticism of the failure of "human rights diplomacy" and of the pragmatic turn taken by the United States}

We find in the articles a strong criticism of the American policy in Burma. Zhou Xinyu shows that, generally, when the US is in a position of strength on the international scene, its foreign policy is determined by arbitrary ideological factors. He gives the example of the two periods that followed the end of World War II and the end of the Cold War, periods during which ideology would have strongly influenced American foreign policy. This notably includes what Zhou calls "human rights diplomacy" (renquan waijiao 人权外交). At the end of the 1980s, this "unilateral and interventionist" (danbianzhuyi, ganshezhuyi 单边主义, 干涉主义) stance notably resulted in American sanctions against Burma. Conversely, when the international political climate for the US deteriorates as it did at the end of the 1970s, American foreign policy seems to show a much more realistic front that places human rights in the background. The 2008 economic crisis and an international context less favourable towards the US could therefore explain the sudden pragmatic turn in American foreign policy, epitomised by Obama's "Asian pivot" strategy of which Burma is a part. For Zhou Xinyu, the Americans have realised the failure of their "human rights policy," which only ended up antagonising the Burmese authorities. It took the US some time to realise that this failure could turn Burma into a new North Korea and that the sanctions were depriving them of the important potential offered by this country. "All the United States could do was to sit and watch the growing influence of China, India, and other powers from the Southeast Asia peninsula in Burma." The United States is now trying to make up for lost time.

According to Zhou Xinyu, Obama's policy in Burma is pragmatic as it is dictated by electoral factors. Obama would have used his foreign policy success to boost his political credential.

Xiao Ke also criticises the purely pragmatic motives of the United States, which only seeks to democratise (here the term is derogatory) and to privatise the economy whilst China seeks first and foremost to settle ethnic conflicts and to encourage the development and economic stability of Burma.

\section{The hidden agenda of the United States: To contain China's influence in Burma}

The authors agree that one of the main goals of American policy in Burma is to contain China within its borders and to prevent it from having too much influence in Burma. But according to Xiao Ke, Burma is only the last link on the chain of American policy in Southeast Asia. Its short-term objective is to make the Association of Southeast Asia Nations (ASEAN) into the "southern 'guardian' of China" (Zhongguo nanbu de "shouwangzhe" 中 国南部的 “守望者”) in the same role that central Asia plays to the west of China and both Japan and South Korea to the east. Here we find again the age-old fear of being surrounded, characteristic of China's foreign policy. Li Yibo's article clearly illustrates this idea with the metaphor of the pond and the water lilies. He describes the "silent" (xiaoxiao 消消) proliferation of American military bases in Asia that, even if harbouring a limited number of soldiers, have at their disposal highly sophisticated and mobile material. He compares this discreet proliferation to the imperceptible movement of water lilies expanding on the surface of a pond: all it takes is for the frog to use these water lilies to jump swiftly on its prey from very far away. As it happens, wherever one may look around China, from the northeast to the southeast of Asia and even in the South Pacific, one observes, according to Li, "a killing machine in disguise" (ancang shaji 暗藏杀机) consisting of bases placed all around China. The missing link in this machine is Burma, which would allow the US to connect its bases in South Asia and in ASEAN countries. ${ }^{(10)}$ Ironically, it is therefore an inverted "String of Pearls" that Li describes.

For Shi Qingren, this policy led by the United States in Burma "exerts pressure on China's strategic space" jiya Zhongguo de zhanlüe kongjian 挤压 中国的战略空间), of which Burma is a part.

The American policy also consists of a worrying dose of soft power that Zhou Xinyu observes "permeating" (shentou 渗透) Burmese society. This soft power, according to Li Yibo, potentially includes military links between the two countries. The invitation extended to Burma to observe the Golden Cobra military exercise between the US and Thailand is a token of this. For Li, the prospect of a military alliance between Burma and the US should worry China, because it would shut down the Burmese solution to the Malacca dilemma.

\section{What prospects for the Sino-Burmese relationship?}

As regards the future posture of Burma, Li Yibo explains that the example of Vietnam, a country that has succeeded in overcoming a historic animosity towards the United States, proves that the 20 years of bad relations between Burma and the US will not be enough to thwart this rapprochement. Burma will have to choose a strategy amongst the many models in Southeast Asia:Thailand's neutrality, Vietnam's position (pro-American and aiming to contain China), the Philippines' alliance with the US, or Cambodia's alignment policy with China.

Amongst all this criticism towards American policy in Burma, Wang Dong adopts an original position. Whilst acknowledging the US's pragmatic policy and its willingness to contain China, Wong laments an excessively regi-

10. The American base in South Asia that Li refers to is no doubt that of Diego Garcia in the Chagos Islands, south of the Maldives. 
mented Chinese diplomacy in Burma. He notes three keys to improving the Sino-Burmese relationships. First and foremost, Chinese "soft power" (ruanshili 软实力) in Burma should be accentuated. It entails sustained lobbying for the removal of sanctions on Burma but also support for educational programs, microcredit schemes, aid for development.... Li Yibo for his part also speaks of a policy to "win the hearts of Burmese people" (yingde miandian renmin de xin 赢得缅甸人民的心). Wang Dong further explains that China must not limit its contacts to the Burmese authorities but should also extend a hand to ethnic minorities and civil society as a whole. Last but not least, Wang notes that if Chinese investment in Burma is to be beneficial, Chinese companies must assume "greater social responsibility" (gengda de shehui zeren 更大的社会责任). Wang Dong openly refers to the social conflicts recently sparked by the construction of the Myitsone dam and exploitation of a copper mine in Sagaing Province. From a Chinese media source, this recommendation is thoroughly original.

Shi Qingren's article is optimistic: he notes that however damaging the US presence, Sino-Burmese relations are too well anchored for the US to shake completely. However, and perhaps we could draw here a parallel with Wang Dong's recommendations, the researcher from the Academy of Military Sciences concludes with a reminder that China would do well to anticipate upcoming difficulties and "repair (consolidate) the house before the storm" (weiyuchoumou 未雨䀦缪).

I Translated by Kate Waller. 